\title{
Morphometric differences and fluctuating asymmetry in Melipona subnitida Ducke 1910 (Hymenoptera: Apidae) in different types of housing
}

\author{
C. B. S. Lima ${ }^{a}$, L. A. Nunes ${ }^{b *}$, C. A. L. Carvalho ${ }^{a}$, M. F. Ribeiro ${ }^{\text {, }}$ \\ B. A. Souza and C. S. B. Silva ${ }^{a}$ \\ aPrograma de Pós-graduação em Ciências Agrárias - PRPPGCA, Universidade Federal do Recôncavo da Bahia - UFRB, \\ Rua Rui Barbosa, 710, Centro, CEP 44380-000, Cruz das Almas, BA, Brazil \\ 'Programa de Pós-graduação em Genética Biodiversidade e Conservação - PPGGBC, Universidade Estadual do Sudoeste \\ da Bahia - UESB, Rua José Moreira Sobrinho, s/n, Jequiezinho, CEP 45206-190, Jequié, BA, Brazil \\ 'Setor de Entomologia, Empresa Brasileira de Pesquisa Agropecuária - Embrapa, Rodovia BR-428, Km 152, \\ Zona Rural, CP 23, CEP 56302-970, Petrolina, PE, Brazil \\ dSetor de Apicultura, Empresa Brasileira de Pesquisa Agropecuária - Embrapa, Av. Duque de Caxias, 5650, \\ Bairro Buenos Aires, CP 001, CEP 64006-220, Teresina, PI, Brazil \\ *e-mail: lorenunes2@gmail.com
}

Received: January 13, 2015 - Accepted: August 26, 2015 - Distributed: November 30, 2016

(With 3 figures)

\begin{abstract}
A geometric morphometrics approach was applied to evaluate differences in forewing patterns of the Jandaira bee (Melipona subnitida Ducke). For this, we studied the presence of fluctuating asymmetry (FA) in forewing shape and size of colonies kept in either rational hive boxes or natural tree trunks. We detected significant FA for wing size as well as wing shape independent of the type of housing (rational box or tree trunks), indicating the overall presence of stress during the development of the studied specimens. FA was also significant $(\mathrm{p}<0.01)$ between rational boxes, possibly related to the use of various models of rational boxes used for keeping stingless bees. In addition, a Principal Component Analysis indicated morphometric variation between bee colonies kept in either rational hive boxes or in tree trunks, that may be related to the different origins of the bees: tree trunk colonies were relocated natural colonies while rational box colonies originated from multiplying other colonies. We conclude that adequate measures should be taken to reduce the amount of stress during bee handling by using standard models of rational boxes that cause the least disruption.
\end{abstract}

Keywords: beekeeping, geometric morphometrics, shape, wing, bee handling.

\section{Diferenças morfométricas e assimetria flutuante em Melipona subnitida Ducke 1910 (Hymenoptera: Apidae) em diferentes tipos de habitação}

\begin{abstract}
Resumo
A abordagem da morfometria geométrica foi aplicada para avaliar as diferenças nos padrões das asas anteriores da abelha Jandaíra (Melipona subnitida Ducke). Para isso, estudou-se a presença de assimetria flutuante (AF) na forma das asas anteriores e tamanho das colônias mantidas tanto em caixas de colméia racional ou troncos de árvores naturais. Foi detectado AF significativa para o tamanho da asa, bem como a forma da asa independente do tipo de habitação (caixa racional ou cortiço), indicando a presença global de estresse durante o desenvolvimento dos espécimes estudados. AF também foi significativa $(\mathrm{p}<0,01)$ entre as caixas racionais, possivelmente relacionados com a utilização de vários modelos de caixas racionais utilizados para a conservação de abelhas sem ferrão. Além disso, a Análise de Componentes Principais indicou variações morfométricas entre as colônias de abelhas mantidos em caixas racionais ou em cortiços, que podem estar relacionados com as diferentes origens das abelhas: os cortiços foram colônias naturais realocados, enquanto as colônias das caixas racionais foram originadas da multiplicação outras colônias. Conclui-se que devem ser tomadas medidas adequadas para reduzir a quantidade de estresse durante o manuseio abelha usando modelos padrão de caixas racionais que causam a menor perturbação.
\end{abstract}

Palavras-chave: meliponicultor, morfometria geométrica, forma, asa, manejo. 


\section{Introduction}

Melipona subnitida occurs naturally in the savannah region of north-eastern Brazil. Commonly used for beekeeping, rational hive boxes are advantageous for bee handling and high yields of honey and other products (Bruening, 2001; Cortopassi-Laurino and Imperatriz-Fonseca, 2001; Lopes et al., 2007; Camargo and Pedro, 2013).

Meliponiculture, the cultivation of native stingless bees in rational hives has been practiced as a leisure activity as well as to exploit hive products as an income source, among other motives. Moreover, it has contributed to the preservation of species (Villas-Boas, 2012).

Traditionally, bees are kept and reared in tree hollows where the colonies naturally build their nests (Nogueira-Neto, 1953; Buchmann, 2006). However, the capture of bee colonies prior to collecting hive products is considered aggressive, and causes stress on the bee colony that results from various disturbances in the nest, including damage to structures, displacement of food pots, loss of larvae and sometimes the death of the queen (Alves et al., 2005). Alternatively, bees can be kept in wooden rational hive boxes, size-specific for each species (Nogueira-Neto, 1953; Buchmann, 2006). Bee development in rational boxes may be influenced by using material that is inappropriate for bee keeping. However, in order to provide an efficient management, beekeepers attempt to adjust boxes for the characteristics of each bee species, taking into account available information about nest architecture and bee biology (Souza et al., 2009).

There are several models of rational boxes for keeping stingless bees. The most suitable one for rearing and reproduction of bees of the Melipona genus is a vertical box, designed by the National Research Institute of Amazonia-INPA. This model allows for less interference by the meliponicultor, permits the colony to recover, and facilitates management by the "Method of Minimal Disruption" (Oliveira and Kerr, 2000).

Despite proper handling, bees experience stress during and after the transfer of colonies to rational boxes especially when opening the tree trunk for nest removal, an aggressive procedure likely to cause breakage of food pots and crushing of young worker bees (Nogueira-Neto, 1997). According to this author, stress to the bees is also caused by the process of honey collection itself: opening the box creates an excess of moisture that interferes with offspring development, produces an imbalance in thermoregulation of the colony and promotes a suitable environment for fungi, among other damages.

The induced stress can impact the ontogenetic development of individuals resulting in asymmetries. Fluctuating asymmetry (FA) is characterized by normally distributed deviations from the bilateral body symmetry of individuals. The presence of differences between the right and left body side is considered an indicator of stress (Clarke, 1998) and is a widely used parameter to evaluate instability and plasticity caused by stressful conditions during the development of organisms (Graham et al., 2010). Rather than being genetically determined, this parameter is mostly influenced by environmental characteristics that affect the ontogeny of individuals (Leamy and Klingenberg, 2005). In addition, FA reflects the degree of population adaptation, making it an important tool for studying the biology of populations (Graham et al., 2010).

Genetic or environmental disturbances that organisms may encounter during their embryonic development must be overcome to allow the expression of the phenotype pre-determined for the species, and can be evaluated by FA. Developmental homeostasis results from the joint action of genes, producing a developmental pattern (Del Lama et al., 2002). Because of the rapid and intense environmental change caused by anthropogenic activities, such as deforestation and pollution, there is growing concern about the ecological and evolutionary consequences of human activities on natural populations (Polak et al., 2002).

Given the need for information about the effect of stress on stingless bee colonies, the present study aims to examine fluctuating asymmetry based on the variation in wing shape and wing size in individuals of $M$. subnitida kept in either rational boxes or trunks.

\section{Material and Methods}

\subsection{Study area}

Sampling was conducted in meliponaries in the states of Alagoas, Bahia and Pernambuco. A total of 634 specimens was collected from 59 nests (41 from rational boxes and 18 from tree trunks). The specimens were placed in falcon tubes containing $70 \%$ alcohol and stored at $-20^{\circ} \mathrm{C}$.

\subsection{Image acquisition}

For imaging, the anterior right and left wings were removed with tweezers and subsequently placed between microscope slides. Photographs were taken with a digital camera mounted on a stereomicroscope for the analysis of venation patterns.

The captured images were transformed to tpsUtil software version 1.40 (Rohlf, 2008a). Ten anatomical landmarks (Figure 1) were inserted at the vein junctions of each wing using tpsDig version 2.17 (Rohlf, 2008b). The images of left wings were mirrored to achieve identical position for left and right wings, facilitating the measurement of anatomical landmarks. For each wing, measurements were duplicated in order to account for measurement errors (Palmer, 1994). The data points obtained were used as variables for statistical analysis.

\subsection{Data analysis}

To evaluate variations in centroid size and shape of wings, a Procrustes ANOVA (Klingenberg and McIntyre, 1998; Palmer and Strobeck, 2003) was conducted with centroid size and shape used as independent variables, body side as fixed effect and individual as random effect (Klingenberg and McIntyre, 1998). Thus, the effect of individual represents individual variation in shape, and the effect of body side represents wing asymmetry. Analyses were performed using the software MorphoJ.

The value for the effect of body side and of individuals was obtained by the denominator of the interaction of 
body side $\mathrm{X}$ individuals obtained by the denominator of the measurement error (Klingenberg and McIntyre, 1998).

Based on the resulting data, a second ANOVA was performed in $\mathrm{R}$ using the Procrustes coordinates of wings to evaluate differences and levels of asymmetry between colonies reared in rational boxes and in tree trunks.

Variation analysis of morphometric divergence for the evaluation of differences between colonies kept in rational boxes and in tree trunks was based on matrices obtained from the anatomical landmark coordinates of the right forewing, which were processed by Procrustes overlay plots, and subsequently analyzed using MANOVA. A covariance matrix was generated for the Principal Component Analysis (PCA). Analyses were performed using the software MorphoJ (Klingenberg, 2011).

\section{Results}

The significant interaction of individual X side (indicating individual variation in size and shape), confirmed the presence of significant wing asymmetry within populations from both types of housing (Tables 1 and $2, \mathrm{p}<0.01$ ).

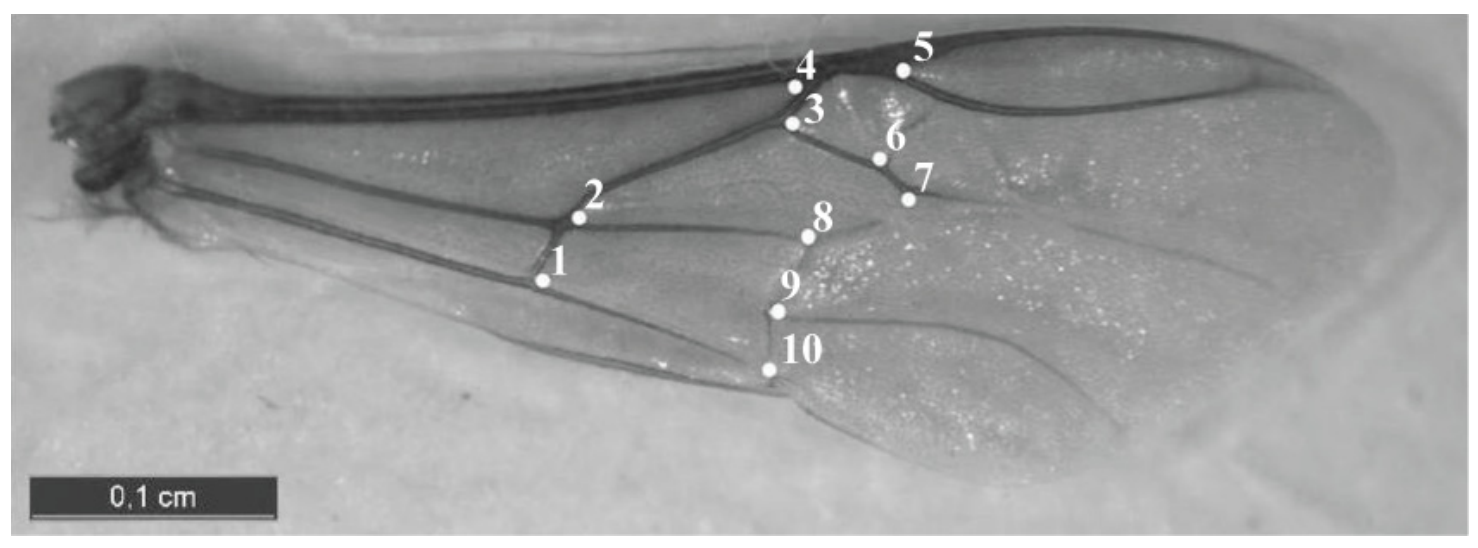

Figure 1. Right forewing of Melipona subnitida with 10 anatomical landmarks scored in the vein junctions and used for morphometric analysis.

Table 1. ANOVA Procrustes analysis of wing size and shape of rational hive box colonies with a significant interaction between the effects of individual and body side.

\begin{tabular}{|c|c|c|c|c|c|c|}
\hline & Effect & SS & MS & df & $\mathbf{F}$ & P (param.) \\
\hline \multirow{5}{*}{ Centroid Size } & Individual & 156.70 & 0.36 & 427 & 560.72 & $<.0001$ \\
\hline & Side & 0.00 & 0.00 & 1 & 0.00 & 0.99 \\
\hline & Ind*Side & 0.27 & 0.00 & 427 & 9.68 & $<.0001$ \\
\hline & Error & 0.05 & 0.00 & 856 & & \\
\hline & Effect & SS & MS & df & $\mathbf{F}$ & $\mathbf{P}$ (param.) \\
\hline \multirow{4}{*}{ Shape } & Individual & 0.79 & 0.00 & 6832 & 5.52 & $<.0001$ \\
\hline & Side & 0.00 & 0.00 & 16 & 26.69 & $<.0001$ \\
\hline & Ind*Side & 0.14 & 0.00 & 6832 & 2.19 & $<.0001$ \\
\hline & Error & 0.13 & 0.00 & 13696 & & \\
\hline
\end{tabular}

Table 2. ANOVA Procrustes analysis of wing size and shape of tree trunk colonies with a significant interaction between the effects of individual and body side.

\begin{tabular}{|c|c|c|c|c|c|c|}
\hline & Effect & SS & MS & df & $\mathbf{F}$ & $\mathbf{P}$ (param.) \\
\hline \multirow{6}{*}{ Centroid Size } & Individual & 4.50 & 0.02 & 198 & 32.89 & $<.0001$ \\
\hline & Side & 0.00 & 0.00 & 1 & 0.98 & 0.3229 \\
\hline & Ind*Side & 0.13 & 0.00 & 198 & 12.01 & $<.0001$ \\
\hline & Error & 0.02 & 0.00 & 398 & 0.03 & 1.00 \\
\hline & Residual & 0.09 & 0.00 & 44 & & \\
\hline & Effect & SS & MS & df & $\mathbf{F}$ & $\mathbf{P}$ (param.) \\
\hline \multirow{5}{*}{ Shape } & Individual & 0.35 & 0.00 & 3168 & 5.38 & $<.0001$ \\
\hline & Side & 0.00 & 0.00 & 16 & 6.15 & $<.0001$ \\
\hline & Ind*Side & 0.06 & 0.00 & 3168 & 2.30 & $<.0001$ \\
\hline & Error & 0.05 & 0.00 & 6368 & 0.30 & 1.00 \\
\hline & Residual & 0.02 & 0.00 & 704 & & \\
\hline
\end{tabular}


For wing shape, we detected the presence of directional asymmetry $(p<0.001)$, but not for wing size $(p>0.05)$, regardless of the type of housing (Table 1 and 2).

Although fluctuating asymmetry in wing form and size was detected in colonies from rational hive boxes and as well as from tree trunks, there was no significant difference $(p>0.05)$ between the two (Figure 2 and Table 3 ).

The first four components of a Principal Component Analysis (used to evaluate morphometric divergence between colonies from the two housing types) explained $65.64 \%$ of the total variation between colonies (PC1 (23.84\%), PC2 (17.92\%) PC3 (1.14\%) and PC4 (9.85\%)). Morphometric variation was independent of the proximity of colonies, bearing in mind that colonies in rational boxes and tree trunks were kept in the same meliponary.
The means for wing shape of Melipona subnitida colonies kept in different types of housing were plotted in two-dimensional space formed by the scores of the first two principal components explaining $23.84 \%$ and $17.92 \%$ of the variance, respectively (Figure 3 ).

Table 3. ANOVA results for fluctuating asymmetry comparisons between two types of bee housing (rational hive boxes and natural tree trunks).

\begin{tabular}{cccccc}
\hline & Df & Sum Sq & Mean Sq & F value & $\operatorname{Pr}(>$ F $)$ \\
\hline Habitat & 1 & 0.00 & $2.3263 \mathrm{e}-05$ & 1.39 & 0.23 \\
Colonies & 60 & 0.00 & $3.5782 \mathrm{e}-05$ & 2.15 & 0.00 \\
Residuals & 565 & 0.00 & $1.6620 \mathrm{e}-05$ & & \\
\hline
\end{tabular}

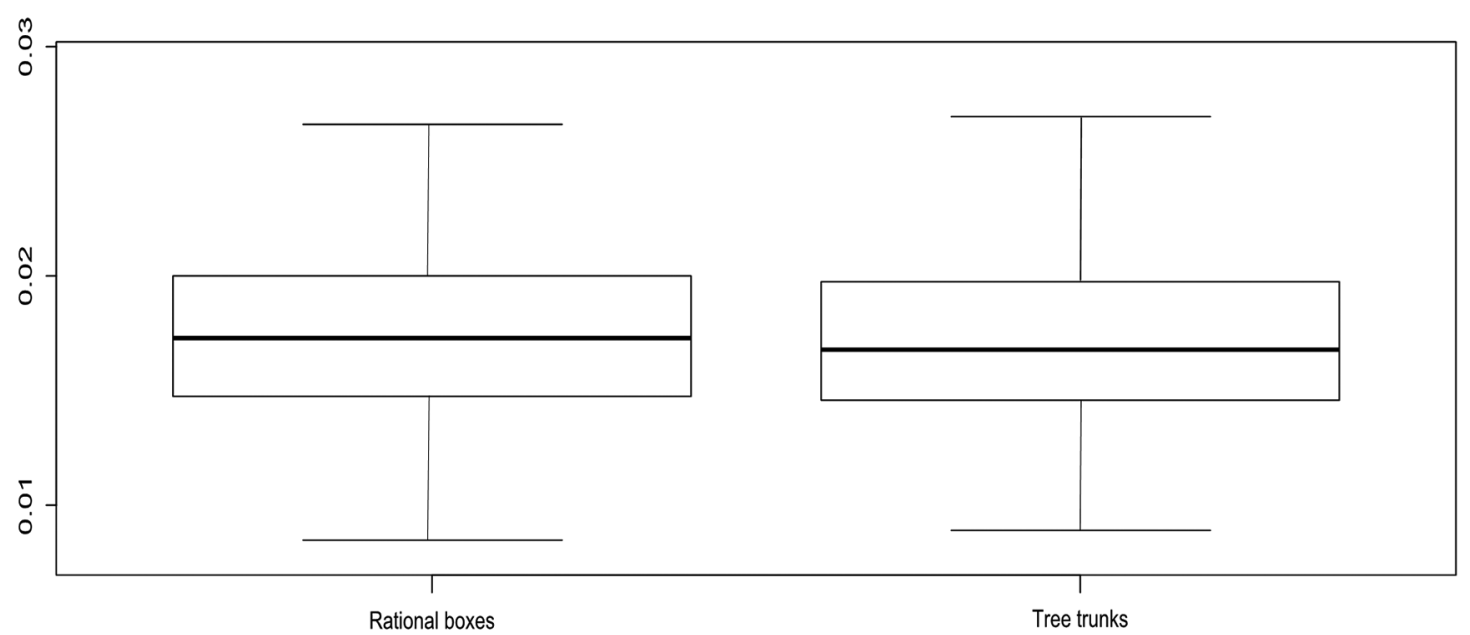

Figure 2. Box plot showing variation of fluctuating asymmetry between nesting environments.

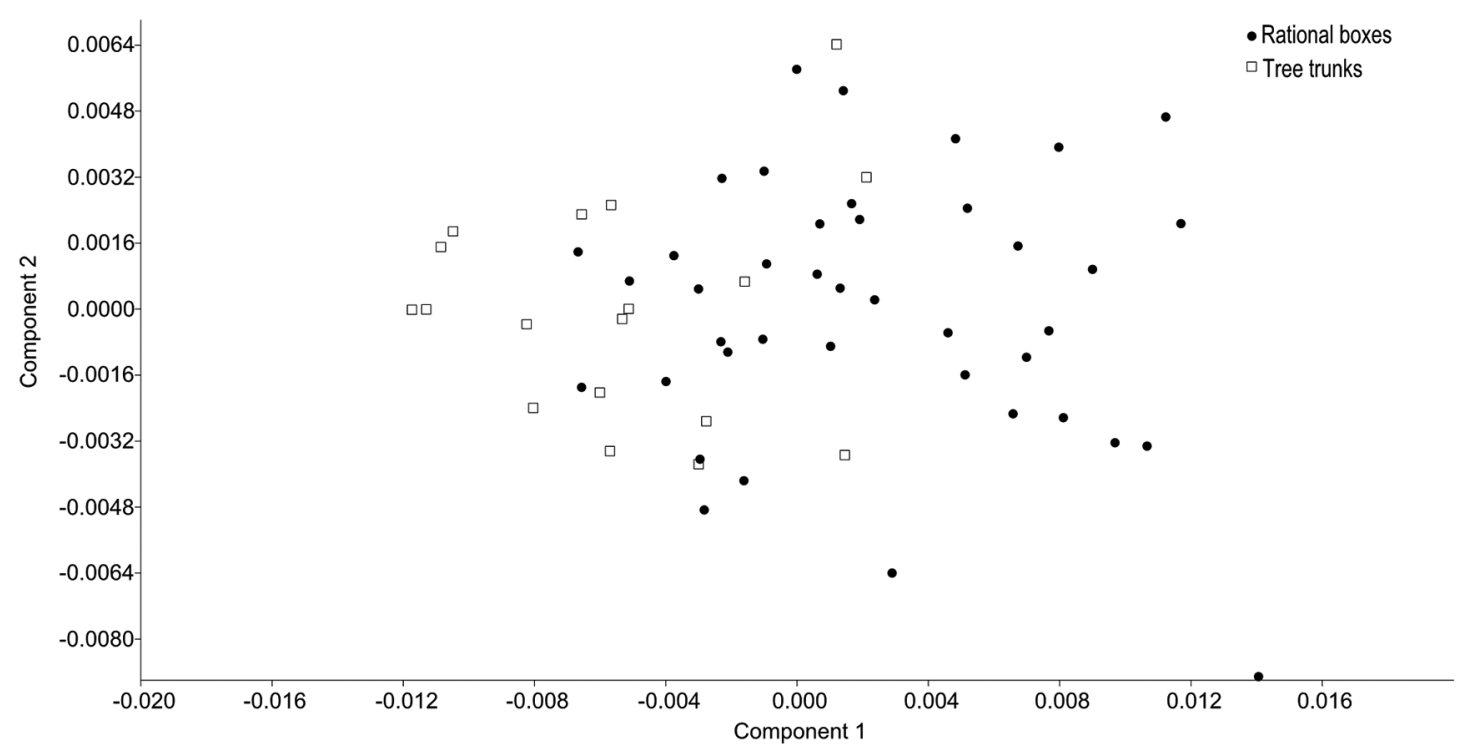

Figure 3. Principal component analysis of wing shape (means) of Melipona subnitida colonies kept in different types of housing, with the first and second principal axes shown (PC1, PC2). 


\section{Discussion}

The significant interaction of individual $\mathrm{X}$ side suggest that stress levels caused by environmental factors such as minimal variations in temperature, sunlight, and scarcity of food resources (Ricklefs, 2009) may directly influence wing size and wing shape of the bees, regardless of their housing conditions. Wing shape is more likely to be influenced by the environment than wing size, where only one of them may be sufficient to indicate the presence of stress during individual development (Nunes et al., 2013).

Smith et al. (1997) suggest that directional asymmetry in bees may be related to the position of larvae, pupae and pre-pupae in the brood cell. It is known that stingless bees kept in either tree trunks or rational hive boxes suffer a certain amount of stress related to the type of housing. Tree trunk colonies may be mainly subjected to environmental stress such as temperature variation and food shortages, while rational hive box colonies are usually subjected to stress caused by human activities such as the frequency of opening the boxes for artificial food supply in times of food shortage, or the harvest of honey (Kerr et al., 1996). Several factors such as heat, lack of food, exposure to sun and rain may exert stress on individuals, thus explaining the variation observed in our results.

Stress caused to bees in rational boxes or trunks may vary during the removal of colonies from the field, transport to the meliponary, and subsequently during the honey gathering process by destruction of food pots and sometimes the death of the queen, the transfer of colonies into boxes, the opening of boxes for feeding, during colony division and related to other characteristics of the boxes and the meliponaries where they are installed.

Although fluctuating asymmetry in wing form and size was detected in colonies from rational hive boxes and as well as from tree trunks, this variation may be related to the use of various models of rational boxes for keeping stingless bees. The box most suitable for rearing and multiplication of bees of the genus Melipona is the INPA model, considered to involve less "meliponicultor" interference during colony recovery and to allow management by the "Method of Minimum Disturbance" (Oliveira and Kerr, 2000). Despite this, most of the rational boxes from which samples were collected were of a different model.

The morphometric divergence between colonies kept in boxes or rational in tree trunks may be explained by the difference in management between the different housing types and management methods. The colonies found in tree trunks are natural colonies, collected in the field and relocated to meliponary generally do not suffer from stress caused by human activities, however, while the colonies kept in rational boxes are obtained by multiplication and division of transferred colonies. The practice of nest multiplication increases the number of colonies within a short period of time, and is widely used due to an interest in the marketing of bee products (Aidar and Campos, 1998).
Fluctuating asymmetry detected in bee wings can be attributed to the presence of stress affecting the colonies, related to handling procedures for each housing type.

\section{Acknowledgements}

The authors thank Empresa Brasileira de Pesquisa Agropecuária (EMBRAPA) (Cod. SEG 02.11.01.029.00.00) for financial support, Coordenação de Aperfeiçoamento de Pessoal de Nivel Superior (CAPES) for the scholarships (C. B. da S. Lima) and Conselho Nacional de Desenvolvimento Científico e Tecnológico (CNPq) (Proc. 305228/2013-7) and the beekeepers who provided samples of bees.

\section{References}

AIDAR, D.S. and CAMPOS, L.A.O., 1998. Manejo e manipulação artificial de colônias de Melipona quadrifasciata Lep. (Apidae: Meliponinae). Annais da Sociedade Entomológica do Brasil, vol. 27, no. 1, pp. 157-159. http://dx.doi.org/10.1590/S030180591998000100021 .

ALVES, R.M.O., SOUZA, B.A., CARVALHO, C.A.L. and JUSTINA, G.D., 2005. Custo de produção de mel: uma proposta para abelhas africanizadas e meliponineos. Cruz das Almas: Universidade Federal da Bahia/SEAGRI-BA. 14 p. Série Meliponicultura, no. 2.

BRUENING, H., 2001. Abelha jandaira. 2nd ed. Mossoró: Fundação Guimarães Duque. Coleção Mossoroense, Série C, vol. $1189.148 \mathrm{p}$.

BUCHMANN, S.L., 2006. Threats to Melipona beecheii colonies and traditional meliponiculture: conservation strategies for restoring stingless bees and forests of the Yucatan Peninsula, Quintana Roo, Mexico. In: Anais do VII Encontro sobre Abelhas, 2006, Ribeirão Preto. Ribeirão Preto: USP. CD- ROM.

CAMARGO, J.M.,F. and PEDRO, S.R.M., 2013 [viewed 12 March 2014]. Meliponini Lepeletier, 1836. In: J.S. Moure, D. Urban and G.A.R. Melo, orgs. Catalogue of bees (Hymenoptera, Apoidea) in the Neotropical Region. Curitiba: Universidade Federal do Paraná. Available from: http://www.moure.cria.org.br/catalogue

CLARKE, G.M., 1998. The genetic basic of developmental stability. IV. Individual and population asymmetry parameters. Heredlty, vol. 80, pp. 553-561. http://dx.doi.org/10.1046/j.13652540.1998.00326.x.

CORTOPASSI-LAURINO, M. and IMPERATRIZ-FONSECA, V.L., 2001. La cria de abejas sin aguijon mas comunes em el Nordeste Brasilero. In: II Seminario Mexicano sobre Abejas Sin Aguijón: Una Visión sobre su Biología y Cultivo, 2001, Mérida. Mérida: Universidad Autónoma de Yucatán, pp. 40-43.

DEL LAMA, M.A., GRUBER, C.V. and GODÓY, I.C., 2002. Heterozigosidade e assimetria do número de hâmulos em operárias adultas de Apis mellifera (Hymenoptera, Apidae). Revista Brasileira de Entomologia, vol. 46, no. 4, pp. 591-595. http:// dx.doi.org/10.1590/S0085-56262002000400014.

GRAHAM, J.H., RAZ, S., HEL-OR, H. and NEVO, E., 2010. Fluctuating asymmetry: methods, theory, and applications. Symmetry, vol. 2, no. 2, pp. 466-540. http://dx.doi.org/10.3390/ sym 2020466 . 
KERR, W.E., CARVALHO, G.A. and NASCIMENTO, V.A., 1996. Abelha Uruçu: biologia, manejo e conservação. Belo Horizonte: Acangaú. 154 p.

KLINGENBERG, C.P. and MCINTYRE, G.S., 1998. Geometric morphometrics of developmental instability: analyzing patterns of fluctuating asymmetry with Procrustes methods. Evolution, Lancaster, vol. 52, no. 5, pp. 1363-1375. http://dx.doi.org/10.2307/2411306.

KLINGENBERG, C.P., 2011. MorphoJ: an integrated software package for geometric morphometrics. Molecular Ecology Resources, vol. 11 , no. 2 , pp. 353-357. http://dx.doi.org/10.1111/j.17550998.2010.02924.x. PMid:21429143.

LEAMY, L.J. and KLINGENBERG, C.P., 2005. The genetics and evolution of fluctuating asymmetry. Annual Reviews of Ecology, Evolution, and Systematics, vol. 36, no. 1, pp. 1-21. http://dx.doi. org/10.1146/annurev.ecolsys.36.102003.152640.

LOPES, M.T.R., SILVA, J.O., PEREIRA, F.M., CAMARGO, R.C.R., VIEIRA-NETO, J.M. and RIBEIRO, V.Q., 2007. Atividade de vôo de abelhas Jandaíra (Melipona subnitida Ducke, 1910) Instaladas em dois modelos de colmeia. Teresina: Embrapa. 20 p. Boletim de Pesquisa e Desenvolvimento, no. 27.

NOGUEIRA-NETO, P., 1953. A criação de abelhas indigenas sem ferrão (Meliponinae). São Paulo: Chácaras e Quintais, 280 p.

NOGUEIRA-NETO, P., 1997. Vida e criação de abelhas sem ferrão. São Paulo: Ed. Nogueirapis, 445 p.

NUNES, L.A., PASSOS, G.B., CARVALHO, C A.L. and ARAÚJO, E.D., 2013. Spatial variation of size and shape of the wing in Melipona quadrifasciata anthidioides Lepeletier, 1836 (Hymenoptera; Meliponini) assessed by geometric morphometrics. Brazilian Journal of Biology $=$ Revista Brasileira de Biologia, vol. 73, pp. 887-893. http://dx.doi.org/10.1590/S1519-69842013000400027.

OLIVEIRA, F. and KERR, W.E., 2000. Divisão de uma colônia de Jupará (Melipona compressipes) usando-se o método Fernando Oliveira. Manaus: INPA. 7 p.
PALMER, A.R., 1994. Fluctuating asymmetry analyses: a primer. In: T.A. Markow, ed. Developmental instability: its origins and evolutionary implications. Dordrecht: Kluwer Academic Publishers, pp. 335-364

PALMER, R.A. and STROBECK, C., 2003. Fluctuating asymmetry analyses revisited. In: M. Polak, ed. Developmental instability (DI): causes and consequences. Oxford: University Press, pp. 279- 319.

POLAK, M.R., OPOKA, R. and CARTWRIGHT, I.L., 2002. Response of fluctuating asymmetry to arsenic toxicity: support for the developmental selection hypothesis. Environmental Pollution, vol. 118, no. 1, pp. 19-28. http://dx.doi.org/10.1016/ S0269-7491(01)00281-0. PMid:11996379.

RICKLEFS, R.E., 2009. A economia da natureza. 5 th ed. Rio de Janeiro: Guanabara Koogan.

ROHLF, F.J. 2008a [accessed 12 March 2013]. tpsUtil. For windows version 1.40 [software]. New York: State University of New York. Available from: http://life.bio.sunysb.edu/morph/ index.html

ROHLF, F.J., 2008b [accessed 12 March 2013]. tpsDig. For windows version 2.17 [software]. New York: State University of New York. Available from: http://life.bio.sunysb.edu/morph/ index.html

SMITH, D.R., CRESPI, B.J. and BOOKSTEIN, F.L., 1997. Fluctuating asymmetry in the honey bee, Apis mellifera: effects of ploidy and hybridization. Journal of Evolutionary Biology, vol. 10, no. 4, pp. 551-574. http://dx.doi.org/10.1007/s000360050041.

SOUZA, D.L., EVANGELISTA-RODRIGUES, A., RIBEIRO, M.N., PADILLAÁLVAREZ, F., FARIAS, E.S.L. and PEREIRA, W.E., 2009. Análises morfométricas entre Apis mellifera da microrregião do sertão Paraibano. Archivos de Zootecnia, vol. 58, no. 221, pp. 65-71. http://dx.doi.org/10.4321/S0004-05922009000100007.

VILLAS-BÔAS, J., 2012. Manual tecnológico de abelhas sem ferrão. Brasília: Ed. ISPN. 